\title{
ŠERIJATSKI ASPEKTI UPOTREBE ALKOHOLA U PROIZVODNJI LIJEKOVA, HRANE I KOZMETIČKIH PREPARATA
}

\section{Sažetak}

Savremena proizvodnja stremi ostvarenju što većeg profita $i$ maksimalnoj eksploataciji sirovina. Pri tome se nerijetko $u$ prehrambene artikle $i$ lijekove unose vjerom zabranjene materije. Musliman je dužan paziti na granice koje je Svevišnji Allah postavio i u svoj organizam unositi samo lijepo, čisto i halal. Alkohol je jedna od tih zabranjenih stvari, međutim zabrana se ne odnosi na sve što se naziva tim imenom. Isto tako, stanje nužde i potrebe razlikuje se od uobičajenog stanja. Ovaj rad ima za cilj rasvijetliti značenje alkohola na koji se odnosi zabrana, ukazati na razlike između opojnog pića $i$ etilnog alkohola, pojasniti propis liječenja haramom, te propis upotrebe alkoholnih pića $i$ etanola u proizvodnji hrane, lijekova $i$ drugog.

Ključne riječi: Alkohol, etanol, alkoholno piće, proizvodnja, lijekovi, farmacija, hrana.

\section{Uvod}

Zahvala Allahu Gospodaru svjetova. Neka su salavati i selami na Allahovog miljenika, odabranog roba i poslanika Muhammeda, njegovu porodicu, ashabe i sve koji njegovu uputu slijede.

Vjera islam svojim propisima osigurava ljudskoj zajednici dostojanstven život kakav priliči čovjeku kao Božijem namjesniku na Zemlji. U obavezu stavlja sve što je nužno da bi čovjek išao putevima duhovnog i materijalnog uspona, a zabranjuje sve što ga vodi u propast i provaliju kakva mu, kao Božijem namjesniku, ne priliči. S tim ciljem zabranjeno je i konzumiranje opojnih pića. Kaže Uzvišeni Allah: $O$ vjernici, vino i kocka i kumiri i strjelice za gatanje su odvratne stvari, šejtanovo djelo; zato se toga klonite da biste postigli što želite. Šejtan želi da pomoću vina i kocke unese među vas neprijateljstvo i mržnju $i$ da vas od sjećanja na Allaha i od obavljanja molitve odvrati. Pa hoćete 
li se okaniti? (El-Maida, 90-91) Zabrana alkoholnih pića opće je poznata, međutim ta zabrana se ne odnosi na sve što se modernim vokabularom naziva alkohol. Isto tako, etilni alkohol (etanol) je primarni sastojak svih alkoholnih pića i odgovoran je za njihovo opojno dejstvo, ali se, u drugoj formi, koristi u svrhe koje nemaju nikakve veze sa alkoholnim pićem. Sve to rezultiralo je mnogim nejasnoćama oko alkohola i propisa njegove upotrebe. Na putu otklanjanja tih nejasnoća nužno je ukazati na značenje pojma alkohol i opojnih pića na koja se odnosi zabrana. Zatim, osvrnuti se na definiciju etilnog alkohola i njegovu korelaciju sa opojnim pićem. Nakon toga, slijedi govor o upotrebi alkoholnih pića i etanola u proizvodnji lijekova, hrane i drugih proizvoda.

\section{Definicija alkohola - opojnog pića}

Riječ alkohol etimološki se veže za arapsku riječ gavl što znači naglo uzeti, ugrabiti, ščepati, uništiti. Alkohol je nazvan ovim imenom jer uzima i uništava razum. Kazujući o džennetskom vinu Svevišnji Allah negira upravo to svojstvo i kaže da u tom vinu nema gavla (la fiha gavl): Od njega neće glava boljeti i od njega se neće pamet gubiti. (Es-Saffat, 47) U kur'ansko-hadiskim tekstovima za opojno piće koristi se izraz khamr. Lingvistički riječ khamr označava pokrivanje i skrivanje. Iz istog korijena uzeta je i riječ khimar koja znači veo, zastor, pokrivač, rubac. Opojno piće nazvano je khamr jer pokriva razum.

U terminologiji islamskog prava, prema velikoj većini učenjaka, khamr je naziv za svako opojno piće, bez obzira bilo ono dobiveno od grožđa, datula, pšenice, ječma ili bilo čega drugog, dok je kod učenjaka hanefijskog mezheba naziv khamr ekskluzivno rezerviran za opojno piće dobiveno od grožđa ${ }^{2}$. U prilog mišljenju većine učenjaka ide hadis Allahovog Poslanika, s.a.v.s., u kojem kaže: „Sve što opija (muskir) je

\footnotetext{
${ }^{1}$ Ibnu Faris - Ahmed b. Faris b. Zekerija, Mekajisul-luga, Darul-fikr, Bejrut, 1399. h.g., 2/174 i Er-Razi - Muhammed b. Ebu Bekr, Muhtarus-sihah, Mektebetu Lubnan, Bejrut, 1415. h.g., str. 196.

${ }^{2}$ Ibnu Kudame - Abdullah b. Ahmed el-Makdisi, El-Mugni, Darul-fikr, Bejrut, 1405. h. g. 10/323 i Ibnu 'Abidin - Muhammed 'Alaud-din el-Efnedi, Redul-muhtar 'aledduril-muhtar, Darul-fikr, Bejrut, 1421. h. g. 4/38.
} 
alkohol (khamr), a sve što opija je haram.“ 3 Kao i riječi drugog pravednog halife Omera, r.a.: „O ljudi, objavljena je zabrana alkohola (khamra) a on se dobivao od petero: grožđa, datula, meda, pšenice i ječma. Alkohol (khamr) je ono što pokriva razum. “ 4

Opća i nacionalna enciklopedija definirajući alkohol spominje da je riječ alkohol arapskog porijekla, a o alkoholnim pićima navodi sljedeće: „Alkoholna pića su pića koja sadrže 3-80 \% etilnog alkohola i dobivaju se alkoholnim vrenjem biljnih sirovina koja sadrže škrob (krompir, žitarice) ili šećer (voće) ili se priređuju miješanjem ekstrakata esencija $i$ vode s etanolom. Poznata su od davnina. Prema količini etanola dijele se na slaba (vino, pivo), srednje jaka (prošek, liker, amaro, i dr.) i jaka (rakija, viski, konjak, vinjak, rum, votka i dr.) Usporavaju reakcije živčanog sustava i u većim količinama štete zdravlju. “ 5

Prema ovoj definiciji pića koja imaju manje od $3 \%$ etilnog alkohola ne spadaju u kategoriju alkoholnih pića. Prema metrici Šerijata alkoholnim pićem se smatra svako piće koje u velikoj količini opija, a ako ne pokazuje opojno dejstvo čak i ako se konzumira u velikoj količini ne tretira se alkoholom. Poslanik, s.a.v.s., je kazao: „Ono što opija u velikoj količini i mali njegov dio je haram. “6 I rekao je: „Kada bi jedna bačva $\left(\right.$ ferek $^{7}$ ) pića opijala i njegova pregršt je haram. ${ }^{\text {“8 }}$ Ukoliko pića

${ }^{3}$ Muslim bin el-Hadždžadž en-Nejsaburi, Sahihu Muslim (Muslimova zbirka hadisa), Daru ihjait-turasil-arabi, Bejrut, bez godine izdanja, br. 2003.

${ }^{4}$ El-Buhari - Muhammed bin Ismail, Sahihul-Buhari (Buharijeva zbirka hadisa), Daruš-Šuab, Kairo, 1987. g., br. 4619, i Muslim, br. 3032.

${ }^{5}$ Enciklopedija - opća i nacionalna, glavni urednik: Vujić Antun, Pro Leksis d.o.o. i Večernji list d.d., Zagreb, 2005. g., I knjiga, str. 140.

${ }^{6}$ Ahmed b. Hanbel eš-Šejbani, El-Musned, Muessesetu Kurtuba, Kairo, br. 14744. Ebu Davud - Sulejman b. El-Eš'as es-Sidžistani, Sunenu Ebi Davud, Darul-fikr, Bejrut, br. 3681. Tirmizi - Muhammed b. 'Isa Ebu 'Isa, Al-Džamius-sahih-sunenutTirmizi, Daru ihjait-turasil-'arabi, Bejrut, br. 1865. Rekao je Tirmizi o ovom hadisu: hasen-garib.

${ }^{7}$ Ferek je posuda veličine 10,0861. kod učenjaka hanefijskog mezheba, a kod drugih iznosi: 8,244 1. Pogledati: Kal'ahdži - Kunejbi, Muhammed Revvas Kal'ahdži i Hamid Sadik Kunejbi, Mu'džemu lugatil-fukaha, Darun-nefais, Bejrut, 1408. h.g., str. 344.

${ }^{8}$ Bilježi Ahmed, br. 24468 i Tirmizi, br. 1866. Rekao je Tirmizi o ovom hadisu: hasen, a Ibnu Mulekkan ga ocjenjuje vjerodostojnim. Pogledati: Ibnu Mulekkan - Siradžud- 
koja sadrže manje od 3 \% etilnog alkohola nemaju opojno dejstvo i kada se konzumiraju u velikoj količini, u tom slučaju se enciklopedijska definicija alkoholnih pića podudara sa šerijatskom.

\section{Definicija etanola - etilnog alkohola}

Etanol je čista prozirna lahko isparljiva tekućina slabog mirisa, nastaje alkoholnim vrenjem šećera i škroba, ulazi u sastav svih alkoholnih pića i odgovoran je za njihovo opojno dejstvo.

U Općoj i nacionalnoj enciklopediji o etanolu navodi se sljedeće: „Etanol (etil-alkohol) $\mathrm{C}_{2} \mathrm{H}_{5} \mathrm{OH}$, obični alkohol, špirit. Miješa se s vodom u svakom omjeru. Sastavni je dio alkoholnih pića. Dobiva se alkoholnim vrenjem razrijeđenih otopina šećera, a industrijski se proizvodi od sirovina bogatih škrobom (krumpir, žitarice) ili od melase. Može se proizvesti i sintetski. Polazna je tvar za proizvodnju mnogih spojeva (eteri, esteri, hloroform, plastične mase, octena kiselina i dr.)“. 9 Špirit je tečnost koja sadrži 89-90 vol. \% etanola. Koncentratni etanol sadrži 95-96 vol. \% etanola, a razblaženi etanol sadrži 69-71 vol. \% etanola. $^{10}$

\section{Ostale vrste alkohola}

U hemijskoj terminologiji alkohol se ne odnosi na opojna pića, nego je to opći termin koji se primjenjuje na sve organske spojeve u kojima je hidroksilna skupina $(\mathrm{OH})$ vezana za ugljikov atom. Neke od tih vrsta alkohola su:

Misanol, proizvodi se od drveta i od prirodnog gasa - metana. Misanolovi derivati se koriste kao sredstva za otapanje u proizvodnji farbe i lakova. Koristi se i kao sredstvo protiv zamrzavanja pogonskog goriva, a može koristiti i kao pogonsko gorivo.

din Ebu Hafs Omer b. 'Ali, El-Bedrul-munir fi tahridži ehadisiš-Šerhil-kebir, Darulhidžreti, Er-Rijad, 1425. h.g., 8/703.

${ }^{9}$ Enciklopedija - opća i nacionalna, glavni urednik: Vujić Antun, VI Knjiga, str. 114.

10 Ibid, I knjiga,,str. 140, i Medicinski leksikon, glavni urednik Mile Medić, Medicinska knjiga Beograd - Zagreb, štamparija: „Bakar“, Bor, 1987. g., str, 747. 
Propanol se proizvodi od etilena i sintetičkog plina. Koristi se kao otapalo u farmaceutskoj industriji za otapanje smola i estera celuloze. Njegovi derivati koriste se u proizvodnji kozmetičkih preparata.

Dodekanol (lauril alkohol) dobiva se iz masne kiseline kokosovog ulja. Koristi se u proizvodnji mazivnih ulja, a u kozmetici se koristi kao ovlaživač. Također se koristi u proizvodnji lijekova, a može se naći i u nekoj hrani kao emulgator. ${ }^{11}$

Ove i slične vrste alkohola nemaju nikakve veze sa opojnim pićem. To su čiste materije u čiju dozvoljenost nema nikakve sumnje.

\section{Upotreba alkoholnih pića u proizvodnji prehrambenih artikala}

Neka alkoholna pića, kao što je rum, brendi, konjak i sl., koriste se za ekstrakciju u proizvodnji određenih vrsta slatkiša, kao što su neke vrste biskvita, torte, čokolada i sladoleda. Alkoholna pića dodaju se ovim proizvodima s ciljem dobivanja određenog okusa traženog kod nekih potrošača. Unošenje alkohola u hranu haram je konsenzusom islamskih učenjaka, jer je to vid konzumiranja onog što je Allah zabranio i naredio da se izbjegava. Hanefijski učenjak El-Merginani kaže: „Pokuđeno je i zabranjeno jesti kruh čije tijesto je zamiješano alkoholom, jer dio alkohola postoji u njemu.“ 12 Malikijski učenjak El-Hattab kaže: „Poznato je, iz riječi Malika i njegovih sljedbenika, da se alkohol ne koristi ni u koju svrhu. “ 13

Imam El-Kurtubi u komentaru kur'anskog ajeta u kojem se o alkoholu kaže: Pa hoćete li se okaniti? (El-Maida, 6) veli: „Ove riječi iziskuju apsolutno ostavljanje alkohola, tako da se ne koristi ni u kakvu svrhu i

\footnotetext{
${ }^{11}$ El-Mevsuatul-arebijjetul-alemijje (Arapska svjetska enciklopedija), Muessesetu a'amalil-mevsua', Er-Rijad, 1416. h.g., 19/154-155 i

https://sh.wikipedia.org/wiki/Dodekanol, preuzeto 17.02. 2016.

${ }^{12}$ El-Merginani, Ebul-Hasan 'Ali b. Ebi Bekr, El-Hidajetu šerhul-Bidajetil-mubtedi, El-Mektebetul-islamije, 4/114.

13 El-Hattab - ك̌semsud-din Ebu Abdullah Muhammed b. Muhammed, MevahibulDželil lišerhi muhtesari Halil, Daru 'alemil-kutub, Er-Rijad, 1423. h.g., 1/171.
} 
ni na koji način: ne konzumiranjem, niti prodajom, niti pretvaranjem $\mathrm{u}$ sirće, niti posluživanjem niti na bilo koji drugi način. “ 14

Ibnu Hazm govoreći o dodavanju malih količina neke od zabranjenih materija u nešto što je halal, kaže: „To neće halal učiniti haramom, ako je haram u maloj i neznatnoj količini tako da se ne osjeti njegov miris, okus niti boja, niti se u tome osjeća trag harama... A ko ubaci nešto od harama $\mathrm{u}$ halal nepokoran je Uzvišenom Allahu. “15

Alkoholno piće, kada se pomiješa sa hranom, iako se ne unosi u organizam u uobičajenom tečnom stanju, unosi se putem jela. Savremeni učenjaci su eksplicitno stavili na znanje da je haram konzumirati namirnice koje u sebi sadrže alkoholno piće ma koliko mali procent alkohola bio. Vijeće islamskih pravnika i medicinara pri Islamskoj organizaciji medicinskih znanosti na svojoj osmoj konferenciji donijelo je sljedeći zaključak: „Nije dozvoljeno konzumiranje hranjivih namirnica koje u sebi sadrže procent alkohola, ma koliko taj procent bio mali, naročito one raširene u zemljama zapada, poput nekih vrsta čokolada, sladoleda i nekih gaziranih sokova, oslanjajući se na šerijatsko pravilo da je sve što opija u velikim količinama zabranjeno i u maloj mjeri. Isto tako, ne postoji ništa na osnovu čega bi se, po metrici šerijata, ovdje napravio izuzetak i to dozvolilo.“"16

\section{Alkoholno piće kao lijek}

Ono što je u prirodnim okolnostima zabranjeno u stanju nužde može postati dozvoljeno. Da li je bolest nužda uslijed koje zabranjeno može postati dozvoljeno ako to liječenje zahtijeva? Da li je alkoholno piće dozvoljeno koristiti kao lijek? Odgovarajući na ova pitanja nužno je ukazati na propis liječenja, tj. da li je bolesnik dužan liječiti se ili ne, i pojasniti šerijatski status liječenja haramom?

\footnotetext{
${ }^{14}$ El-Kurtubi - Ebu Abdullah Muhammed bin Ahmed, El-Džami'u li ahkamil-Kur'ani, Darul-kutubil-misrije, Kairo, 1384. h.g., 6/289.

${ }^{15}$ Ibnu Hazm, Ebu Muhammed 'Ali b. Ahmed ez-Zahiri, El-Muhala šerhul-mudžella, Darul-fikr, Bejrut, 6/100.

${ }^{16}$ Ez-Zuhejli Vehbe, El-Fikhul-islami ve ediletuhu, Darul-Fikr, Damask, 1405. h.g., $7 / 211$.
} 


\section{Da li je liječenje obavezno?}

Ibrahim, a.s., opisuje svog Gospodara riječima: Koji me je stvorio i na Pravi put uputio, $i$ koji me hrani i poji, $i$ koji me, kad se razbolim, liječi. ( Ěs-Šuara: 78-80). Allah je taj koji daje život i smrt i bolest i lijek. Nijedan lijek neće koristiti osim Allahovom dozvolom. U to čvrsto vjeruje svaki musliman. Ipak, to nikako ne znači da se materijalni uzroci mogu zanemariti. Poslanik, s.a.v.s., govorio je: „Allah nije spustio bolest a da za nju nije spustio lijek. " ${ }^{17} \mathrm{U}$ drugoj predaj još je dodano: „Ko ga je upoznao zna za njega, a ko ga nije upoznao ne zna za njega.“ ${ }^{18}$ Usame b. Šurejk, r.a., prenosi da je Allahov Poslanik, s.a.v.s., rekao: „Liječite se, jer doista Svevišnji Allah nije dao bolest a da za nju nije dao i lijek, osim jedne, a to je starost.“ 19 Ove predaje odgovor su ekstremistima koji vjeruju da potpunost oslonca na Allaha podrazumijeva ostavljanje liječenja i materijalnih uzroka. Zapostavljanje uzroka, također je u koliziji sa praksom Allahovog Poslanika, s.a.v.s., i njegovom cjelokupnom biografijom, kroz koju se jasno vidi da nije zanemarivao uzroke, nego je činio sve što je u njegovoj moći, uz čvrsto oslanjanje na Allaha i ubjeđenje da uzroci daju svoje rezultate samo ako to Allah dozvoli. Svojom riječi i djelom potvrdio je da davanje uzroka ne negira tevekul-oslonac na Allaha, nego je to ispravno percipiranje vjere i Allahovih zakona u prirodi.

Hadis u kojem Poslanik, s.a.v.s., opisujući skupinu iz ovog ummeta koja će ući u Džennet bez polaganja računa, kaže: „To su oni koji ne zloslute, koji ne traže da im se uči rukja (da im se naučava) i koji ne vrše kauterizaciju (ne liječe se vatrom), nego se na Gospodara svoga oslanjaju. “ ${ }^{20}$, na ukazuje na pokuđenost liječenja niti da liječenje negira potpunost oslonca na Allaha. Ibnu Usejmin, rahimehullah, o ovom hadisu kaže: „To se ne odnosi na onog ko traži ljekarsku pomoć, jer Vjerovjesnik, s.a.v.s., nije rekao: Ne liječe se!, nego je rekao: 'Ne liječe se vatrom i ne traže da im se naučava.' Međutim, izuzima se stanje kada se srce čovjeka veže za ljekara, kao i nada u ozdravljenje i strah od

\footnotetext{
${ }^{17}$ Buharija, br. 5678 .

${ }^{18}$ Ahmed, br. 3578 .

${ }^{19}$ Ebu Davud, br. 3855 i Tirmizi, br. 2038. Rekao je Tirmizi o ovom hadisu: hasensahih.

${ }^{20}$ Buharija, br. 5752 i Muslim, br. 371.
} 
bolesti. Takvo stanje u srcu čovjeka skrnavi njegov oslonac na Allaha Uzvišenog. Kada se čovjek uputi ljekaru neka vjeruje da je to samo davanje uzroka, da rezultat dolazi isključivo od Svevišnjeg Allaha, i da je On Taj u čijoj ruci je izlječenje. Tako će oslonac na Allaha biti potpun." 21

Islamski pravnici raspravljali su o propisu liječenja i o tome iznijeli različita mišljenja, od kojih je preferirajuće da se propis razlikuje shodno stanju bolesnika. Islamski pravni kolegij na svojoj sedmoj konferenciji, na kojoj se raspravljalo o ovoj temi, izišao je sa zaključkom u kojem je detaljno pojašnjeno kada je liječenje obavezno a kada samo dozvoljeno ili pohvalno. U zaključku se navodi: „Liječenje je propisano, jer na to ukazuje Kur'an, riječi i djelo Allahovog Poslanika, s.a.v.s., te korist koju ostvaruje čuvanjem života što je jedan od visokih ciljeva Šerijata. Sam propis liječenja razlikuje se shodno stanju i okolnostima. Tako je liječenje obavezno onom ko ostavljenjem liječenja dovodi svoj život u opasnost ili rizikuje da izgubi neki dio tijela ili njegovu funkciju, ili da se pak bolest prenese na druge. Liječenje je pohvalno ukoliko ostavljanje liječenja rezultira slabljenjem tijela, ali ne vodi onom što je spomenuto u prethodnom slučaju. Dozvoljeno je ako ne spada u prethodna dva stanja. Pokuđeno je ukoliko se čini na način tako da postoji bojazan da uzrokuje težu bolest od postojeće.“ 22

\section{Liječenje haramom}

Sve što postoji na Zemlji halal je i dozvoljeno izuzev skupine materija koje je islam zabranio. Smisao zabrane u prvom redu je da Uzvišeni Allah iskuša Svoje robove, jer kroz prihvatanje naredbi i zabrana praktično se potvrđuje iskrenost u vjeri, zadovoljstvo Allahom kao Gospodarom, Muhammedom poslanikom i islamom vjerom. Pored toga, sve zabranjeno čovjeku donosi štetu, a ako u sebi ima kakve koristi, šteta u njemu veća je od koristi. Svevišnji Allah o vinu i kocki

${ }^{21}$ El-'Usejmin - Muhammed b. Salih, Fetava nur 'alad-derb, El-Mektebetuš-šamile, $3 / 213$.

22 Zaključak Kolegija islamskog prava pri Organizaciji islamskog kongresa u Džiddi, br. 7/5/69, na temu Medicina i liječenje, deveta redovna sjednica održana u Džiddi, 1992. Medželetu Medžme'il-fikhil-islami, 7/3/729, El-Mektebetuš-šamile, 7/2321. 
kaže: Pitaju te o vinu i kocki. Reci: 'Oni donose veliku štetu, a i neku korist ljudima, samo je šteta od njih veća od koristi.' (El-Bekara, 219) Većina zabranjenih materija spomenuta je u Kur'anu i sunnetu, poput: vina, svinjetine, uginulih kopnenih životinja, pri klanju prolivene krvi, divljih zvijeri, ptica grabljivica, nečistih tvari i slično. Neke od ovih materija koriste se u pripremi lijekova. Tako se na primjer svinjski derivati koriste u proizvodnji određenih lijekova, kao što je Heparin, a koriste se i u proizvodnji kapsula. Obzirom da se lijek koristi samo kada za njim postoji potreba ili nužda, islamski pravnici raspravljali su o propisu liječenja zabranjenim materijama ili lijekovima u čije sastojke ulazi nešto od zabranjenih tvari. Nakon što su se složili da nije dozvoljeno koristiti lijek sačinjen od haram sastojaka ukoliko ima alternativu u dozvoljenim lijekovima učenjaci se razilaze po pitanju njegove upotrebe kada za njega nema učinkovite zamjene. Malikijski i hanbelijski učenjaci zauzeli su oštriji stav dok su hanefije i šafije liberalniji po ovom pitanju.

Hanefijski učenjak Ibnu 'Abidin kaže: „Ono što je ranije kazano da je liječenje haramom haram ne odnosi se na svaku situaciju, jer liječenje haramom nije dozvoljeno ukoliko se ne zna da je u njemu lijek, a kada se to zna i ne postoji drugi lijek, dozvoljeno je.“ 23

Šafijski učenjak Er-Remli, nakon što je ukazao na zabranu liječenja opojnim pićem nepomiješanim s drugim tvarima, kaže: „Međutim, ako je opojno piće razloženo u drugom lijeku dozvoljeno je liječiti se njime, kao što je dozvoljeno liječiti se drugim nečistim tvarima mimo opojnih pića čak i ako nisu pomiješane drugim supstancama, ako bolesnik zna, ili ga obavijesti pouzdan ljekar, da je taj lijek djelotvoran i koristan, te da je nužno baš taj lijek upotrijebiti i da ga čist (halal) lijek ne može zamijeniti.“ 24

Malikijski učenja Ed-Dirdir kaže: „Nije dozvoljeno upotrijebiti alkohol kao lijek, pa i ako se strahuje za život." ${ }^{25}$ Malikije generaliziraju ovaj propis na sve nečiste i zabranjene tvari, svejedno liječilo se njima

\footnotetext{
${ }^{23}$ Ibnu 'Abidin, Redul-muhtar 'ala ed-duril-muhtar, 5/228.

${ }^{24}$ Er-Remli - Šemsud-din Muhammed b. Ebi Abbas Šihabud-din, Nihajetul-muhtadž ila šerhil-minhaď̌, Darul-fikr, Bejrut, 2/14.

25 Ed-Dusuki - Šemsud-din, Hašijetud-Dusuki 'ala Eš-Šerhil-kebir, Ihjaul-kutubil'arabije, 19/38.
} 
unošenjem u organizam ili nanošenjem na tijelo, te bila zabranjena tvar stoprocentna ili pomiješana sa dozvoljenom. Samo u jednom stanju dozvoljavaju liječenje haramom, a to je da liječenje bude vanjskom upotrebom, tj. nanošenjem na kožu, a ostavljanjem lijeka život se dovodi u opasnost.

Henbelijski učenjak Ibnu Kudame kaže: „Nije dozvoljeno liječiti se haramom niti nečim što u sebi sadrži haram, poput magarećeg mlijeka i mesa zabranjenih životinja, niti je dozvoljeno piti alkohol radi lijeka." ${ }^{\text {26 }}$

Učenjaci koji liječenje zabranjenim tvarima vide dozvoljenim, kada neme druge alternative, argumentiraju svoj stav kur'anskim ajetom: Allah vam je objasnio šta vam je zabranio - osim kad ste u nevolji. (ElEn'am, 119) Ovim ajetom Svevišnji Allah ukazuje da u slučaju nužde ono što je zabranjeno postaje dozvoljenim, a liječenje je nužno, što znači da je liječenje zabranjenim dozvoljeno, ukoliko ne postoji drugi lijek. Drugi dokaz ovog mišljenja je predaja o ljudima iz plemena Urejne kada su se dolaskom u Medinu razboljeli, pa im je Poslanik, s.a.v.s., dozvolio da se liječe pijući mlijeko i mokraću kamila. ${ }^{27}$ Isto tako, dozvolio je upotrebu zlata u medicinske svrhe i oblačenje svilene odjeće bolesnim od svraba, iako su zlato i svila zabranjeni muškarcima.

S druge strane učenjaci koji ne dozvoljavaju liječenje zabranjenim tvarima argumentiraju svoj stav općim ajetima i hadisima koji zabranjuju te materije, poput ajeta: Zabranjuje vam se strv, $i$ krv, $i$ svinjsko meso... (El-Maida, 3) Ta zabrana je univerzalna i obuhvata sva stanja osim ona koja izuzmu validni dokazi, poput utoljenja gladi nečim od spomenutog kada se ne nalazi druga hrana. Zatim kao dokaz navode niz predaja od kojih su riječi Poslanika, s.a.v.s., o opojnom piću pripremljenom za lijek: „To nije lijek nego je to bolest.“28 Ummu Seleme, r.a., rekla je: „Moja kćerka se razboljela pa sam za nju u posudi pripremila napitak koji je kisio. Utom je ušao Poslanik, s.a.v.s., i upitao: 'Šta je to?', rekla sam: Moja kćerka se razboljela pa sam joj napravila ovaj napitak, a on na to reče: 'Uzvišeni Allah, doista nije učinio da vam

\footnotetext{
${ }^{26}$ Ibnu Kudame, El-Mugni, 11/83.

${ }^{27}$ Buharija, br. 1501 i Muslim, br. 1671.

${ }^{28}$ Muslim, br. 1984.
} 
lijek bude u haramu." 29 Također se prenosi od Ibnu Mes'uda, r.a., da je o opojnom piću kazao identičan govor. ${ }^{30}$ A prenosi se i da je Allahov Poslanik, s.a.v.s., rekao: „Svevišnji Allah spustio je bolest i lijek, i učinio da za svaku bolest postoji lijek, zato: liječite se, ali se nemojte liječiti haramom. “31

Analizirajući prethodna mišljenja i njihove argumente može se zaključiti da je dužnost klonuti se svega što je vjerom zabranjeno čak i ako se radi o lijeku. Ipak, lijek sačinjen od zabranjenih materija dozvoljeno je koristiti u mjeri koja je neophodna ukoliko za njim postoji stvarna potreba, nema alternativnih lijekova, a njegovo ljekovito djelovanje je potvrđeno. Ova olakšica ne obuhvata opojna pića, jer eksplicitne i vjerodostojne predaje ukazuju da opojna pića nisu lijek i da ih nije dozvoljeno koristiti u tu svrhu.

Prema tome, alkoholna pića nije dozvoljeno koristiti kao lijek niti ih je dozvoljeno upotrebljavati u proizvodnji lijekova. Praktično, danas se alkoholna pića, kao lijek koriste samo u narodnoj medicini, dok se u konvencionalnoj medicini ne koriste u svrhu liječenja. Razlog leži u tome što je znanstveno potvrđeno da alkoholna pića štete a ne koriste ${ }^{32}$,

${ }^{29}$ Ebu Ja'la - Ahmed b. 'Ali Et-Temimi, Musned Ebi Ja'la, valorizacija: Husejn Selim Esed, Darul-Me'mun lit-turas, Damask, 1404. h.g., br. 6966. Ibnu Hibban Muhammed b. Hibban b. Ahmed Et-Temimi, Sahihu Ibnu Hibban bi tertibi Ibni Bulban, valorizacija: Šuajb Arnaut, Muessesetur-risale, Bejrut, 1418. h.g., br. 1391. El-Bejhaki - Ahmed b. El-Husejn b. 'Ali Ebu Bekr, Sunenul-Bejhaki el-Kubra, Mektebetud-daril-Baz, Mekka, 1414. h.g., br. 19463. Hadis je dobar po ocjeni Husejn Selim Eseda.

${ }^{30}$ Bilježi Buharija- bez seneda, koristeći frazu koja ukazuje na vjerodostojnost, 7/143, Bejhaki, br. 19464 i Hakim - Muhammed b. Abdullah en-Nejsaburi, El-Mustedrak 'alas-sahihajni, darul-kutubil-'ilmije, Bejrut, 1411.h.g., br. 7509. Predaju je vjerodostojnom ocijenio Es-Sehavi. Pogledati: Es-Sehavi - Šemsud-din Muhammed b. Abdurrahman, El-Mekasidul-hasene fi bejani kesirin minel-ehadisil-muštehire 'alael-elsine, Darul-kitabil-'arabi, str. 200.

31 Ebu Davud, br. 3847. Predaju je slabom ocijenio imam Nevevi. Pogledati: EnNevevi - Muhjud-din Jahja b. Šeref, El-Medžmu' - ̌̌erhul-Muhezzeb liš-Širazi, Darulfikr, Bejrut, 5/106.

${ }^{32}$ El-Bar - Muhammed 'Ali, Elkuhul vel-muhaddiratu vel-munebbihatu fil-gizai veddevai, studija objavljena u znanstvenom listu Kolegija islamskog prava pri Rabiti islamskog svijeta, Mekka, 1421. h.g., 13/350-357. 
baš kao što je Allahov Poslanik, s.a.v.s., o alkoholnom piću kazao: „To nije lijek, već je to bolest. ‘33

\section{Razlika između alkoholnog pića i etanola}

Iako je etanol primarni sastojak svih alkoholnih pića i odgovoran je za njihovo opojno dejstvo, preče je tretirati ga zasebnom tvari, različitom od alkoholnog pića. Razlog tome su brojne razlike između njih, od kojih su najbitnije sljedeće:

Prvo: U sastav alkoholnih pića, pored etanola, ulaze brojne druge komponente, koje formiraju okus, boju, miris i druga svojstva specifična alkoholnim pićima. Ti sastojci imaju ključnu ulogu u formiranju alkoholnog pića valjanog za upotrebu.

Drugo: Alkoholna pića su pripremljena za piće a njihovo konzumiranje uzrokuje opojnost, dok čisti etilni alkohol nije pripremljen za piće a njegovo konzumiranje uzrokuje trovanje.

Treće: Osnovni cilj proizvodnje alkoholnog pića je da se koristi kao opojni napitak, dok je osnovni cilj proizvodnje etanola da se koristi kao polazna tvar za proizvodnju raznih spojeva, kao što su eteri, esteri, plastične mase i sl., da služi kao sredstvo za razgradnju biljnih otopina, eteričnih ulja, za dezinfekciju i sl..

Četvrto: Etanol je čista prozirna lahko isparljiva tekućina, slabog mirisa, kada se ostavi na bilo kojoj površini brzo isparava i ne ostavlja nikakav trag ili mrlju, za razliku od alkoholnog pića. ${ }^{34}$

Ove razlike ukazuju da je etanol materija koja se esencijalno razlikuje od alkoholnih pića, iako je njihova primarna komponenta. Prema tome, propis alkoholnih pića se ne odnosi izravno na etanol. To znači da zabrana alkoholnog pića, koja podrazumijeva ne samo zabranu konzumiranja nego i zabranu proizvodnje, kupovine, prodaje i sl., ne odnosi se izravno na etanol, međutim nameće se pitanje: Da li je dozvoljeno koristiti etanol u proizvodnji ili ne? Propis upotrebe etanola

\footnotetext{
${ }^{33}$ Muslim, br. 1984.

34 El-Mevsuatul-arebijjetul-alemijje (Arapska svjetska enciklopedija), Muessesetu a'malil-mevsua, Er-Rijad, 1416. h.g., 19/155, i Nezih Hammad, El-Mevadulmuharremetu ven-nedžise fil-gizai ved-devai bejnen-nazarijjeti vet-tatbik, Darulkalem, Damask, 1425.h.g., str. 48-49.
} 
nije jednak u svim granama proizvodnje, a obzirom da se etanol može upotrijebiti za proizvodnju alkoholnog pića njegova upotreba $u$ proizvodnji mora biti ograničena i kontrolirana.

\section{Načini upotreba etanola u farmaceutskoj industriji}

Etanol se koristi u proizvodnji lijekova u sljedeće svrhe:

Prvo: Za rastapanje nekih lužastih ili masnih tvari koje se koriste kao lijekovi. Ovo je najbitnija i najraširenija primjena etanola u proizvodnji lijekova. Upotrebljava se za dva osnovna cilja: prvi je odvajanje učinkovitih ekstrakata iz ljekovitog bilja, i to je najbitnija primjena. Drugi je dobivanje otopina rastvaranjem ljekovitih tvari koje se otapaju u etanolu, kada se žele koristiti kao otopine a ne u nekom drugom obliku.

Drugo: Etanol se koristi kao konzervans i sredstvo za čuvanje, obzirom da uništava bakterije i mikrobe, a lijekovi trebaju sredstvo za zaštitu od vrenja za vrijeme pripreme i nakon toga kako se ne bi pokvarili i uništili. Etanol je tvar koja se najviše koristi na tom polju.

Treće: Etanol se koristi kao ekstrakt za dobivanje određenog okusa kako bi se bolesniku olakšalo uzimanje lijeka. Radi postizanja okusa etanol se kao ekscipijent dodaje lijekovima u velikom procentu, koji prosječno dostiže $25 \%$.

Četvrto: Ponekad se etanol unosi u visokom postotku u lijekove namijenjene za djecu kao sedativ ${ }^{35}$.

To su najčešće upotrebe etanola u proizvodnji lijekova. U slične svrhe koristi se i u proizvodnji nekih prehrambenih artikala.

\section{Opravdanost upotrebe etanola u proizvodnji lijekova}

Očigledno je da upotreba etanola za ekstrakciju i dobivanje arome i okusa alkohola nije dozvoljena niti za tim postoji potreba, kod nas muslimana. Što se tiče ostalih vidova upotrebe etanola u proizvodnji lijekova muslimani su dužni uložiti maksimalan napor da iznađu

\footnotetext{
${ }^{35}$ El-Bar - Muhammed 'Ali, Elkuhul vel-muhaddiratu vel-munebbihatu fil-gizai veddevai, 13/350-357 i El-Feki - Hasan b. Ahmed, Ahkamul-Edvijeti fiš-šerijatilislamijje, Mektebetud-daril-minhadž, Er-Rijad, 1430.h.g., str. 281.
} 
zamjenu za etanol kako bi se izbjegla njegova upotreba u spomenute svrhe. Da li adekvatna zamjena etanolu postoji ili ne, decidan odgovor trebaju dati stručnjaci iz te oblasti, a da alternativa etanolu postoji ukazuje sljedeće:

Prvo: Postoje druge materije koje mogu zamijeniti etanol pri rastvaranju i otapanju ljekovitih tvari, kao što je voda. Voda je najvažniji i najrasprostranjeniji rastvarač a istovremeno je najsigurnija i najjeftinija. Voda rastvara većinu spojeva i prikladna je za odvajanje učinkovitih ekstrakata u prirodnom bilju, sama ili uz dodatak drugih pomoćnih otapala, poput kiseline $\mathrm{i}$ glicerina. Organski rastvarači, poput hloroforma, otapaju učinkovite ekstrakte koji se ne rastvaraju u vodi, i oni su prikladna zamjena etanolu za otapanje tvari koje se ne rastvaraju u vodi. Zatim, biljna ulja, poput maslinovog i ulja sjemenki pamuka, kvalitetno otapaju aromatične supstance. Postoje i druge alternative obzirom da se otapanje može pospješiti hemijskim reakcijama koje podstiču rastvaranje različitih tvari.

Drugo: Etanola kao konzervans i sredstvo za čuvanje nije nužan, jer postoje desetine drugih konzervansa, a neki od njih su učinkovitiji od etanola, poput natrij-benzoata, glicerina i hloroforma. Šta više, neki farmaceutski proizvodi u tečnom stanju nužno zahtijevaju druge konzervanse osim etanola, u protivnom će se pokvariti, jer etanol gubi svojstvo konzervansa nakon što se razrijedi osnovnom tekućom bazom, a nemoguće je povećati njegov postotak, jer to povećava prisustvo etanola u lijeku što opet daje različite neželjene učinke.

Treće: Upotreba etanola kao sedativa ima štetne posljedice po djecu i trudnice. Pri kontinuiranoj upotrebi utječe na razvoj mozga i inteligencije djeteta, ako se daje djeci za vrijeme dojenja. Iz tog razloga je Svjetska zdravstvena organizacija (WHO) zabranila upotrebu etanola $\mathrm{u}$ proizvodima namijenjenim djeci i trudnicama, a ukoliko se nalazi u lijeku nužno je da na ambalaži bude navedeno u kom procentu je prisutan.

Četvrto: Farmaceutske kompanije u stanju su iznaći druge alternative kada za tim postoji volja. To se praktično već desilo, jer su uspjele zamijeniti etanol i odstraniti ga iz nekih lijekova namijenjenih za djecu, poput sirupa Quibron i Gripe Water, u čijim sastojcima je bio etanol. Naime, Sjedinjene Američke Države su zabranile upotrebu etanola u 
proizvodnji dječjih lijekova povodom incidenta sa lijekom za astmu, koji je u sebi sadržavao etanol. Ljekari su taj lijek propisivali kao sirup za djecu, a obzirom da je astma kronična bolest, neku djecu je, dužom upotrebom tog lijeka, zahvatilo štetno djelovanje etanola. Nakon toga su Sjedinjene Američke Države zabranile upotrebu etanola u proizvodnji većine lijekova za djecu. Farmaceutska industrija uspjela je pronaći alternativu etanolu nakon što je zabranjena njegova upotreba $u$ proizvodnji ove vrste lijekova, isto tako moguće je u proizvodnji drugih lijekova. Naročito kada se uzme u obzir da velike kompanije posjeduju ogromne znanstvene i tehničke preduvjete za pronalazak adekvatne zamjene etanolu. ${ }^{36}$

\section{Propis upotrebe etanola u proizvodnji lijekova}

Vijeća islamskih učenjaka eksplicitno su istakla da su muslimani dužni iznaći zamjenu etanolu i udaljiti ga iz upotrebe u proizvodnji lijekova.

Islamski pravni kolegij pri Rabiti u svom zaključku iznosi: „Islamski pravni kolegij preporučuje kompanijama za proizvodnju lijekova i farmaceutima u islamskim zemljama i uvoznicima lijekova da ulože sve napore kako bi se etanol udaljio od lijekova i da se koriste druge alternative. Isto tako, kolegij oporučuje ljekarima da ne propisuju lijekove koje u sebi sadrže alkohol koliko je to više moguće.“37

Stalna komisija za fetve u Saudijskoj Arabiji na ovu temu u svojoj fetvi navodi: „Nije dozvoljeno miješati lijekove opojnim alkoholom, međutim, ako bi se pomiješali sa alkoholom dozvoljena je njihova upotreba ukoliko je procent alkohola mali tako da se ne primjeti njegov

\footnotetext{
${ }^{36}$ El-Bar - Muhammed 'Ali, Elkuhul vel-muhaddiratu vel-munebbihatu fil-gizai veddevai, 13/351 - 357, El-Feki - Hasan b. Ahmed, Ahkamul-Edvijeti fiš-šerijatilislamijje, str. 291 - 292, Abdul-Fettah Mahmud Idris, Istihdamul-kuhuli fil-gizai veddevai vet-ta'kim, Medželetul buhusil-fikhijetil-muasire, Metabiu' daril-buhusi, ErRijad, 1417.h.g., 35/126.

${ }^{37}$ Zaključak broj šest na šesnaestoj redovnoj sjednici održanoj u Mekki, ševval 1422 h. g. Pogledati: El-Džizani - Muhammed b. Husejn, Fikhun-Nevazil, Daru IbnilDževzi, Ed-Demmam, 1427.h.g., 4/179.
} 
trag na boji lijeka, okusu ili mirisu, u protivnom haram je koristiti lijek pomiješan sa alkoholom. “ 38

Dakle, etanol nije dozvoljeno unositi u lijekove i nužno je pronaći alternativu u dozvoljenim materijama. Međutim, ako je etanol nezamjenjiv u proizvodnji određene vrste lijeka, čija učinkovitost je potvrđena, a taj lijek nema alternative u liječenju bolesnika, $\mathrm{u}$ tom slučaju dozvoljena je upotreba etanola, na način da se ne osjeti njegov trag u okusu, boji ili mirisu i da lijek nema opojno dejstvo.

Već je ranije preferirana dozvola liječenja zabranjenim materijama kada je to nužno, izuzev alkoholnih pića, koja nisu lijek i nije ih dozvoljeno koristiti ni u kom slučaju. Stoga, nije dozvoljeno unijeti količinu etanola koja će nastalu smjesu učiniti opojnom, jer u tom slučaju poprimit će propis alkoholnog pića. Kada je to nužno, etanol se dodaje u maloj količini tako da se rasprši u osnovnoj supstanci bez da ostavi ikakav trag u okusu, boji ili mirisu. To potvrđuje konstatacija učenjaka šafijskog mezheba koji u kontekstu govora o liječenju alkoholom kažu: „Tačka po kojoj se razilazimo je liječenje čistim alkoholnim pićem, a što se tiče seruma pripremljenog alkoholom i tome slične smjese u kojima se rasprši i utroši, time je dozvoljeno liječiti se kada nema druge alternative u dozvoljenim tvarima kojima se ostvaruje liječenje. To je poput liječenje nečistim tvarima, kao što je meso zmije i mokraća. Isti je propis ako se radi o ubrzanju liječenja, uz uvjet da pouzdan ljekar iz redova muslimana potvrdi da je u tome lijek, ili ako (pacijent) sam poznaje liječenje time.“ 39

Islamski pravni kolegij pri Rabiti, nakon što je pozvao muslimanske zemlje da ulože maksimalan trud u odstranjivanju alkohola iz proizvodnje lijekova ukazuje na dozvolu upotrebe lijekova koji u sebi sadrže neznatan procent alkohola kada za tim postoji potreba, lijek nema alternativu a propisao ga je pouzdan ljekar. U zaključku Kolegija navodi se sljedeće: „Dozvoljeno je uzimati lijekove koji u svojim sastojcima sadrže alkohol u niskim procentima, tako da je utrošen i

38 Fetava El-Ledžnetid-daime, El-medžmuatul-ula ves-sanije, sabrao: Ahmed bin Abdur-rezak ed-Duvejš, Riasetu idaretil-buhusil-'ilmijjeti vel-ifta, Er-Rijad, 1422.h.g., 25/30.

${ }^{39}$ Eš-Širbini - Muhammed b. Ahmed el-Hattab, Mugnil-Muhtadži ila marifeti elfazilMinhadži, Darul-kutubil-'ilmijje, 5/518. 
raspršen, a iziskuje ga proizvodnja lijekova koji nemaju alternativu, uz uvjet da taj lijek propiše pouzdan ljekar.“40

\section{Propis upotrebe etanola u prehrambenoj industriji}

Upotrebe etanola u proizvodnji prehrambenih artikala kao sredstvo za ekstrakciju zabranjena je konsenzusom islamskih učenjaka ${ }^{41}$. Također je zabranjena upotreba etanola za otapanje i konzerviranje hrane. Upotrebom etanola pri otapanju ili konzerviranju hrane dio etanola ostaje u hrani. Taj dio, iako je mali, zabranjen je u hrani i piću, jer je Allahov Poslanik, s.a.v.s., zabranio konzumiranje alkohola u maloj kao i u velikoj mjeri. Rekao je: „Ono što opija u velikoj količini i mali njegov dio je haram.“ 42 I rekao je: „Ako jedna bačva pića opija, i njegova pregršt je haram. “43

Već smo ranije prenijeli zaključak Vijeća islamskih pravnika i fetvu Stalne komisije u kojima se poziva na potpun prekid upotrebe etanola u proizvodnji lijekova. Udaljiti ga iz proizvodnje hrane još je preče, jer prehrambene artikle konzumiraju svi, dok lijekove koristi samo ko je u potrebi. Svevišnji Allah zabranio je alkoholna pića i naredio da ih se klonimo, a etanol je primarni sastojak svih opojnih pića i odgovoran je za opojno dejstvo. Stoga je dužnost klonuti ga se, naročito kada se uzme u obzir da postoje druge materije koje mogu zamijeniti etanol u procesu proizvodnje lijekova, a isto tako i hrane.

Obzirom da se etanol tretira zasebnom materijom, drugačijom od opojnog pića, zbog bitnih razlika među njima na koje smo ranije

${ }^{40}$ Zaključak broj šest na šesnaestoj redovnoj sjednici održanoj u Mekki, ševval 1422 h. g. Pogledati: El-Džizani, Fikhun-Nevazil, 4/179.

41 Ibnu Hazm - Ebu Muhammed 'Ali b. Ahmed Ez-Zahiri, Meratibul-idžma' fil'ibadati vel-mu'amelati vel-i'tikadati, Darul-kutubil-'ilmijje, Bejrut, str. 137. To se razumije iz konstatacije Ibnu Hazma da su učenjaci jednoglasno složni po pitanju zabrane hrane pomiješane sa alkoholom ako se osjeća njegov miris, boja ili okus.

42 Ahmed, br. 14744, Ebu Davud, br. 3681 i Tirmizi, br. 1865. Rekao je Tirmizi o ovom hadisu: hasen-garib.

43 Ahmed, br. 24468 i Tirmizi, br. 1866. Rekao je Tirmizi o ovom hadisu: hasen, a Ibnu Mulekkan ga ocjenjuje vjerodostojnim. Pogledati: Ibnu Mulekan El-Bedrulmunir, 8/703. 
ukazali, njegova upotreba u proizvodnji hrane se, u uskim granicama, može tolerisati kada se ispune sljedeći uvjeti:

Prvo: Da etanol nema alternativu i da za njim postoji potreba.

Drugo: Da se ne osjeti njegov trag u okusu, boji ili mirisu.

Treće: Da proizvod u čijoj pripremi se koristi etanol, ma koliko se konzumirao ne uzrokuje opojnost.

Četvrto: Da se koristi za pripremu lijeka ili neke od osnovnih namirnica, a ne za pripremu poslastica i tome sličnog.

\section{Upotreba etanola u proizvodnji kozmetičkih preparata}

Etanol se koristi u proizvodnji različitih kozmetičkih preparata a naročito mirisa, jer se koristi kao rastvarač eteričnih ulja, sastavni je dio pjene za brijanje, boja za kosu, nekih vrsta šampona i brojnih drugih preparata. Koristi se za dezinfekciju hirurških instrumenta, medicinskog pribora i kože, a koristi se i kao pogonsko gorivo ili dodatak gorivu. ${ }^{44}$

Propis upotrebe etanola u spomenute svrhe i upotrebe preparata u čijim sastojcima ima etanola istraživalo je Vijeće islamskih pravnika i medicinara pri Islamskoj organizaciji medicinskih znanosti nakon čega je Vijeće donijelo sljedeći zaključak: „Materija etanol vjerski se tretira čistom, bazirajući se na ranije potvrđeno pravilo da je osnova u svim stvarima čistoća, svejedno radilo se o čistom etanolu ili razrijeđenom vodom, preferirajući mišljenje da je nečistoća alkoholnih pića apstraktna a ne osjetilna. Prema tome, vjerski nema smetnje da se etanol upotrebljava u medicinske svrhe kao dezinfekcijsko sredstvo za kožu, rane i pribor, te sredstvo za uništavanje bakterija, kao što nema smetnje u upotrebi parfemskih mirisa (kolonjske vode) u kojima se koristi etanol kao sredstvo za otapanje mirisne raspršene tvari, ili da se upotrebljavaju balzami u čijem sastavu ima etanola. Ovaj propis se ne odnosi na alkoholna pića, jer je haram njima se koristiti.“ 45

${ }^{4}$ El-Mevsuatul-arebijjetul-alemijje, 19/154, i Rebi'u el-Hadž Hasan, Mevsuatul'utur, Darul-M'arife, Bejrut, 2007.g., str. 38.

${ }^{45}$ El-Mevsuatul-arebijjetul-alemijje, 19/154, 
Obzirom da je etanol zasebna materija koja se esencijalno razlikuje od opojnih pića, nema smetnje da se etanol koristi u ovom ogranku proizvodnje kao dodatna komponenta ili otapalo pri proizvodnji dezinfekcionih sredstava, krema, mirisa i sl. Etanol je čista materija za kojom postoji potreba te je njena upotreba u proizvodnji ove vrste artikala u osnovi dozvoljena. Međutim, etanol je materija koja se koristi na spomenuti način ali se može upotrijebiti i za proizvodnju alkoholnih pića. Zbog te mogućnosti potrebno je preventivno djelovati i iznalaziti druge materije koje bi zamijenile etanol, ili anulirati mogućnost upotrebe etanola za proizvodnju alkoholnih pića tako da se etanol pomiješa sa metanolom ili drugim hemijskim tvarima. Na takav način postupaju mnogi proizvođači etanola kako bi izbjegli poreze koje nameću vlade brojnih zemalja s ciljem kontrole proizvodnje i distribucije etanola ${ }^{46}$, a spriječiti proizvodnju alkohola je prioritetnije.

\section{Zaključak}

Na kraju ove studije možemo konstatovati sljedeće:

- Prema definiciji Opće i nacionalne enciklopedije pića koja imaju manje od $3 \%$ etilnog alkohola ne spadaju u kategoriju alkoholnih pića. Ukoliko pića koja sadrže manje od $3 \%$ etilnog alkohola ako bi se konzumirala u velikoj količini nemaju opojno dejstvo, u tom slučaju je ova definicija ekvivalentna definiciji opojnog pića (khamra) u šerijatskoj terminologiji.

- Etanol je čista prozirna lahko isparljiva tekućina slabog mirisa, nastaje alkoholnim vrenjem šećera i škroba, ulazi u sastav svih alkoholnih pića i odgovoran je za njihovo opojno dejstvo.

- U hemijskoj terminologiji alkohol se ne odnosi na opojna pića, nego je to opći termin koji se primjenjuje na sve organske spojeve u kojima je hidroksilna skupina $(\mathrm{OH})$ vezana za ugljikov atom. Šerijatski tekstovi koji zabranjuju alkohol ne odnose se na te vrste alkohola nego se odnose na opojna pića u čijem sastavu je etanol.

${ }^{46}$ Ibid, 19/155, 
- Unošenje alkoholnog pića u hranu haram je konsenzusom islamskih učenjaka, jer je to vid konzumiranja onog što je Allah zabranio i naredio da se izbjegava.

- Liječenje je u osnovi dozvoljeno, a obavezno je onom ko ostavljanjem liječenja dovodi svoj život u opasnost, rizikuje da izgubi neki dio tijela ili njegovu funkciju, ili da se pak bolest prenese na druge. Pokuđeno je ukoliko se čini na način tako da postoji bojazan da uzrokuje težu bolest od postojeće. Davanje uzroka ne negira oslonac na Allaha, nego je to ispravno percipiranje vjere i Allahovih zakona u prirodi.

- Dužnost je klonuti se svega što je vjerom zabranjeno čak i ako se radi o lijeku. Ipak, lijek sačinjen od zabranjenih materija dozvoljeno je koristiti u mjeri koja je neophodna ukoliko za njim postoji stvarna potreba, nema alternativnih lijekova, a njegovo ljekovito djelovanje je potvrđeno. Ova olakšice ne obuhvata opojna pića, jer eksplicitne i vjerodostojne predaje ukazuju da opojna pića nisu lijek i da ih nije dozvoljeno koristiti u tu svrhu.

- Čisti etilni alkohol (špirit) esencijalno se razlikuje od opojnih pića i tretira se posebnom materijom.

- Etanol se, u proizvodnji lijekova, najčešće koristi za rastapanje, konzerviranje i ekstrakciju. Upotreba etanola kao ekstrakta za dobivanje arome i okusa alkohola nije dozvoljena niti za tim postoji potreba, a za ostale svrhe u koje se koristi etanol farmaceutske kompanije u stanju su iznaći alternativu.

- Muslimani su dužni iznaći zamjenu etanolu i udaljiti ga iz proizvodnje lijekova i hrane. Ako je etanol nezamjenjiv u proizvodnji određene vrste lijeka, čija učinkovitost je potvrđena, a taj lijek nema alternative, u tom slučaju, zbog prijeke potrebe, dozvoljena je upotreba etanola, na način da se ne osjeti njegov trag u okusu, boji ili mirisu i da lijek nema opojno dejstvo.

- Upotrebe etanola u proizvodnji prehrambenih artikala kao sredstvo za ekstrakciju zabranjena je konsenzusom islamskih učenjaka. Također je zabranjena upotreba etanola za otapanje i konzerviranje hrane. Upotreba etanola u proizvodnji hrane može se tolerisati samo u uskim granicama kada se ispune striktni uvjeti. 
- Upotreba etanola u proizvodnji neprehrambenih artikala, poput krema, mirisa, dezinfekcionih sredstava i sl. je dozvoljena. Obzirom da se miješanjem ekstrakata, esencije i vode s etanolom priređuje alkoholno piće potrebno je iznalaziti zamjene etanolu, ili anulirati mogućnosti njegove upotrebe za proizvodnju alkoholnih pića miješanjem etanola sa drugim hemijskim tvarima.

\section{Literatura}

1. Abdul-Fettah Mahmud Idris, Istihdamul-kuhuli fil-gizai ved-devai vet-ta'kim, Medželetul buhusil-fikhijetil-muasire, Metabiu' darilbuhusi, Er-Rijad, 1417.h.g.

2. Ahmed b. Hanbel eš-Šejbani, El-Musned, Muessesetu Kurtuba, Kairo.

3. Ebu Davud - Sulejman b. El-Eš'as es-Sidžistani, Sunenu Ebi Davud, Darul-fikr, Bejrut.

4. Ebu Ja'la - Ahmed b. 'Ali Et-Temimi, Musned Ebi Ja'la, valorizacija: Husejn Selim Esed, Darul-Me'mun lit-turas, Damask, 1404. h.g.

5. Ed-Dusuki - Šemsud-din, Hašijetud-Dusuki 'ala Eš-Šerhil-kebir, Ihjaul-kutubil-'arabijje.

6. El-Bar-Muhammed 'Ali, Elkuhul vel-muhaddiratu velmunebbihatu fil-gizai ved-devai, studija objavljena u znanstvenom listu Kolegija islamskog prava pri Rabiti islamskog svijeta, Mekka, 1421. h.g.

7. El-Bejhaki - Ahmed b. El-Husejn b. 'Ali Ebu Bekr, Sunenul-Bejhaki el-Kubra, Mektebetud-daril-Baz, Mekka, 1414. h.g.

8. El-Buhari - Muhammed bin Ismail, Sahihul-Buhari (Buharijeva zbirka hadisa), Daruš-Šuab, Kairo, 1987. g.

9. El-Džizani - Muhammed b. Husejn, Fikhun-Nevazil, Daru IbnilDževzi, Ed-Demmam, 1427.h.g.

10. El-Feki - Hasan b. Ahmed, Ahkamul-Edvijeti fiš-šerijatil-islamijje, Mektebetud-daril-minhadž, Er-Rijad, 1430.h.g.

11. El-Hattab - Šemsud-din Ebu Abdullah Muhammed b. Muhammed, Mevahibul-Dželil lišerhi muhtesari Halil, Daru 'alemil-kutub, ErRijad, 1423. h.g.

12. El-Kurtubi - Ebu Abdullah Muhammed bin Ahmed, El-Džami'u li ahkamil-Kur'ani, Darul-kutubil-misrije, Kairo, 1384. h.g. 
13. El-Merginani, Ebul-Hasan 'Ali b. Ebi Bekr, El-Hidajetu šerhulBidajetil-mubtedi, El-Mektebetul-islamije.

14. El-Mevsuatul-arebijjetul-alemijje (Arapska svjetska enciklopedija), Muessesetu a'malil-mevsua, Er-Rijad, 1416. h.g.

15. El-'Usejmin - Muhammed b. Salih, Fetava nur 'alad-derb, ElMektebetuš-šamile.

16. Enciklopedija - opća i nacionalna, glavni urednik: Vujić Antun, Pro Leksis d.o.o. i Večernji list d.d., Zagreb, 2005. g.

17. En-Nevevi - Muhjud-din Jahja b. Šeref, El-Medžmu' - šerhulMuhezzeb liš-Širazi, Darul-fikr, Bejrut.

18. Er-Razi - Muhammed b. Ebu Bekr, Muhtarus-sihah, Mektebetu Lubnan, Bejrut, 1415. h.g.

19. Er-Remli - Šemsud-din Muhammed b. Ebi Abbas Šihabud-din, Nihajetul-muhtadži ila šerhil-minhadž, Darul-fikr, Bejrut.

20. Es-Sehavi - Šemsud-din Muhammed b. Abdurrahman, ElMekasidul-hasene fi bejani kesirin minel-ehadisil-muštehire 'alaelelsine, Darul-kitabil-'arabi.

21. Eš-Širbini - Muhammed b. Ahmed el-Hattab, Mugnil-Muhtadži ila marifeti elfazil-Minhadži, Darul-kutubil-'ilmijje.

22. Et-Tirmizi - Muhammed b. 'Isa Ebu 'Isa, El-Džamius-sahih sunenut-Tirmizi, Daru ihjait-turasil-'arabi, Bejrut.

23. Ez-Zuhejli Vehbe, El-Fikhul-islami ve ediletuhu, Darul-Fikr, Damask, 1405. h.g.

24. Fetava El-Ledžnetid-daime, el-medžmuatul-ula ves-sanije, sabrao: Ahmed bin Abdur-Rezak ed-Duvejšs, Riasetu idaretil-buhusil'ilmijjeti vel-ifta, Er-Rijad, 1422.h.g.

25. Hakim - Muhammed b. Abdullah en-Nejsaburi, El-Mustedrak'alassahihajni, darul-kutubil-'ilmijje, Bejrut, 1411.h.g.

26. Ibnu 'Abidin - Muhammed Alaud-din el-Efnedi, Redul-muhtar 'ala ed-duril-muhtar, Darul-fikr, Bejrut, 1421. h.g.

27. Ibnu Faris - Ahmed b. Faris b. Zekerija, Mekajisul-luga, Darul-fikr, Bejrut, 1399. h.g.

28. Ibnu Hazm - Ebu Muhammed 'Ali b. Ahmed ez-Zahiri, Meratibulidžma' fil-'ibadati vel-mu'amelati vel-i'tikadati, Darul-kutubil'ilmijje, Bejrut.

29. Ibnu Hazm, Ebu Muhammed 'Ali b. Ahmed ez-Zahiri, El-Muhala šerhul-mudžella, Darul-fikr, Bejrut. 
30. Ibnu Hibban - Muhammed b. Hibban b. Ahmed Et-Temimi, Sahihu Ibnu Hibban bi tertibi Ibni Bulban, valorizacija: Šuajb Arnaut, Muessesetur-risale, Bejrut, 1418. h.g.

31. Ibnu Kudame - Abdullah b. Ahmed el-Makdisi, El-Mugni, Darulfikr, Bejrut, 1405. h.g.

32. Ibnu Mulekkan - Siradžud-din Ebu Hafs Omer b. 'Ali, El-Bedrulmunir fi tahridži ehadisiš-Šerhil-kebir, Darul-hidžreti, Er-Rijad, 1425. h.g.

33. Kal'ahdži - Kunejbi, Muhammed Revvas Kal'ahdži i Hamid Sadik Kunejbi, Mu'džemu lugatil-fukaha, Darun-nefais, Bejrut, 1408. h.g.

34. Medicinski leksikon, glavni urednik Mile Medić, Medicinska knjiga Beograd - Zagreb, Štamparija: „Bakar“, Bor, 1987. g.

35. Medželetu Medžme'il-fikhil-islami ettabi' limunezzametilmutemeril-islami bi Džidde, el'aded essabi', El-Mektebetuš-šamile.

36. Muslim bin el-Hadždžadž en-Nejsaburi, Sahihu Muslim (Muslimova zbirka hadisa), Daru ihjait-turasil-arabi, Bejrut, bez godine izdanja.

37. Nezih Hammad, El-Mevadul-muharremetu ven-nedžise fil-gizai ved-devai bejnen-nazarijjeti vet-tatbik, Darul-kalem, Damask, 1425.h.g.

38. Rebi'u el-Hadž Hasan, Mevsuatul-'utur, Darul-M'arife, Bejrut, 2007.g. 
Hakija Kanurić, $\mathrm{PhD}$

\title{
SHARI'AH ASPECTS OF ALCOHOL USAGE IN THE PRODUCTION OF MEDICINE, FOOD AND COSMETIC PRODUCTS
}

\begin{abstract}
Modern manufacture aims to achieve considerable profit and a maximum exploitation of the raw materials. Ingredients which are probibited by faith are very often put in nutritional items and medicine during the manufacturing proces. A Muslim is required to pay attention to the limits of the Almighty Allah and to put in his body only that which is nice, clean and halal.

Alcohol is one of those prohibited items, but its prohibiton does not apply to everything which is called by that name. Likewise, the state of emergency and need differs from normal conditions. This work aims to clarify the meaning of an alcohol which is prohibited, to indicate the difference between a fermented drink and ethyl alcohol, to clarify treatment by Haram substances, and a regulation of use of alcohol and ethanol in the production of food, medicines and other.
\end{abstract}

Keywords: alcohol, ethyl alcohol, alcoholic beverage, manufacturing, medicine, pharmacy, food. 


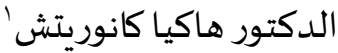

الجوانب الشرعية في استعمال الكحول في إنتاج الأدوية والأطعمة ومستحضرات التجميل

\section{الخلاصة}

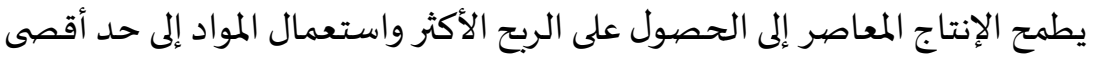

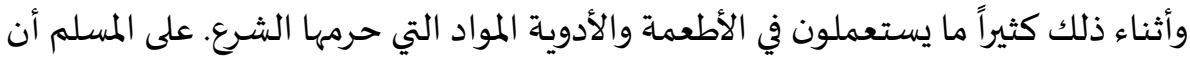

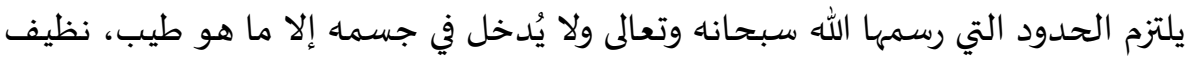

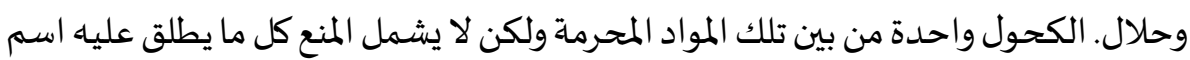

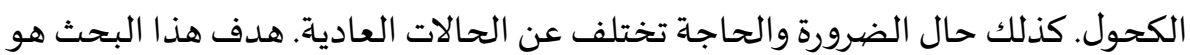

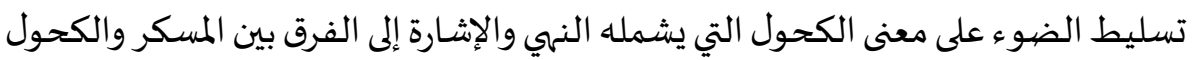

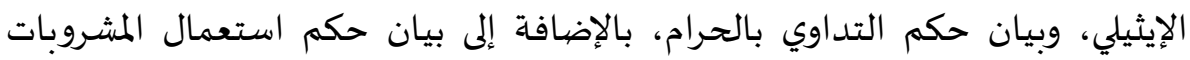
الكحولية والإيثيلي في إنتاج الأطعمة والأدوية وغيرهما.

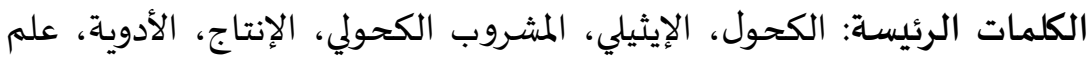
الأدوية، الطعام 